\title{
STUDI KOMPARASI MOTIVASI BELAJAR SISWA MATA PELAJARAN IPS ANTARA YANG DIAJARKAN DENGAN GAYA MENGAJAR EKSPOSITORI DAN CERAMAH PADA KELAS VIII SMPN 6 SEMARANG
}

\section{Amir Mukti, Arif Purnomo, Asep Ginanjar Program Studi Pendidikan IPS UNNES}

Amirmukti96@gmail.com

\begin{abstract}
IPS not just learning the process of interaction between educators and learners with learning resources in a certain environment, with ekspositori learning strategies teachers were able to control the sequence and extent of learning material, he can know the extent to which students master learning materials delivered. Through the learning strategy ekspositori in addition to the students can be heard through the utterance of a learning material, also at once students can see or observing (through the implementation of the demonstration). Obstacles faced by IPS teacher at SMP 6 Semarang is the presumption IPS in the lessons students are always related to memorize and write so much. This resulted in students are not motivated to focus during the following lesson IPS. Although for most students still consider the lessons of IPS is the preferred lesson..
\end{abstract}

Keywords:Expositori Teaching Style, Learning Motivation.

\begin{abstract}
Abstrak
Pembelajaran IPS bukan sekedar proses interaksi antara peserta didik dengan pendidik dan sumber belajar dalam lingkungan tertentu, Dengan strategi pembelajaran ekspositori guru mampu mengontrol urutan dan keluasan materi pembelajaran, ia dapat mengetahui sampai sejauh mana siswa menguasai bahan pembelajaran yang disampaikan. Melalui strategi pembelajaran ekspositori selain siswa dapat mendengar melalui penuturan tentang suatu materi pembelajaran, juga sekaligus siswa bisa melihat atau mengobservasi (melalui pelaksanaan demonstrasi). Kendala yang dihadapi oleh guru IPS di SMPN 6 Semarang ialah anggapan para siswa dalam pelajaran IPS selalu berkaitan dengan menghafal dan menulis yang begitu banyak. Hal ini yang mengakibatkan siswa tidak termotivasi untuk fokus selama mengikuti pelajaran IPS. Walaupun bagi sebagian siswa masih banyak yang menganggap pelajaran IPS merupakan pelajaran yang disukai.
\end{abstract}

Kata kunci: Gaya Mengajar, Ekspositori, MotivasiBelajar 


\section{PENDAHULUAN}

Seiring dengan perkembangan zaman, dunia pendidikan mau tidak mau juga turut berjalan mengikuti perubahan untuk memenuhi perannya sebagai pencetak insan masa depan. Upaya memperbaiki dan meningkatkan mutu pendidikan seakan tidak pernah berhenti. Bukan hanya perubahan dalam sektor kurikulum, tetapi juga diikuti perubahan praktik pembelajaran didalam maupun diluar kelas. mengadakan variasi merupakan ketrampilan yang harus dikuasai guru dalam pembelajaran, untuk mengatasi kebosanan peserta didik, agar selalu antusias, tekun, dan penuh motivasi. Variasi dalam pembelajaran adalah perubahan dalam proses kegiatan untuk meningkatkan motivasi belajar peserta didik, serta mengurangi kejenuhan dan kebosanan (Mulyasa, 2008:78). Salah satunya yaitu variasi dalam gaya mengajar. Menurut Donald Medley dalam Nani (2013:140-141) gaya mengajar guru adalah kemampuan guru untuk menciptakan iklim kelas (classroom climate).

Gaya mengajar guru merupakan hal yang sangat penting dalam proses pembelajaran karena sangat mempengaruhi motivasi siswa dalam belajar. Jika guru tidak memiliki gaya mengajar yang baik, maka besar pengaruhnya bagi peserta didik. Dari gaya mengajar tersebut guru dapat menggunakan cara atau metode yang digunakan guru ketika sedang melakukan pengajaran untuk mengatasi siswa agar tidak merasa bosan dalam proses belajar mengajar. Pada dasarnya gaya mengajar yang dimiliki guru adalah strategi yang digunakan untuk mentransfer informasi yang diberikan kepada siswa agar memiliki motivasi belajar.

Motivasi adalah aspek yang sangat penting untuk proses belajar mengajar siswa. Tanpa adanya motivasi, tidak mungkin siswa memiliki kemauan untuk belajar. Oleh karena itu membangkitan motivasi merupakan salah satu peran dan tugas guru, dalam setiap proses pembelajaran, motivasi dapat diartikan sebagai dorongan yang memungkinkan siswa untuk bertindak atau melakukan sesuatu. Dorongan itu hanya muncul dalam diri siswa manakala siswa merasa membutuhkan. Siswa yang merasa butuh akan bergerak dengan sendirinya untuk memenuhi kebutuhanya.

Kendala yang dihadapi oleh guru IPS di SMPN 6 Semarang ialah para siswa yang menganggap pelajaran IPS selalu berkaitan dengan menghafal dan menulis yang begitu banyak, hal ini yang mengakibatkan siswa tidak termotivasi untuk fokus selama mengikuti pelajaran IPS. Walaupun bagi sebagian siswa masih banyak yang menganggap bahwa pelajaran IPS merupakan pelajaran yang di sukai.

Gaya mengajar guru mata pelajaran IPS di SMPN 6 Semarang yang sering dilakukan lebih mengutamakan pada ceramah klasik serta peran guru yang dominan di dalam kelas. Hal ini menyebabkan 
siswa merasa bosan serta mengantuk saat pelajaran IPS berlangsung, suasana gaduh juga sering terlihat ketika pelajaran berlangsung.

Menurut beberapa siswa, hal ini dipengaruhi oleh cara mengajar guru dalam menyampaikan materi yang terlihat membosankan oleh siswa. Dilihat dalam proses belajar siswa yang berlangsung di kelas, siswa juga kurang aktif, sebagian siswa hanya diam, dan beberapa orang siswa tidak memperhatikan guru waktu menjelaskan. Hal ini menunjukan bahwa siswa tidak memiliki motivasi dalam proses belajar mengajar dikelas.

\section{Gaya mengajar ekspositori}

Penyampaian materi pelajaran merupakan ciri utama dalam pembelajaran ekspositori, namun tidak berati proses penyampaian materi tanpa tujuan pembelajaran. Justru tujuan itulah yang harus menjadi pertimbangan utama dalam penggunaan strategi atau gaya mengajar ini. karena itu sebelum strategi ini diterapkan terlebih dahulu guru harus merumuskan tujuan pembelajaran secara jelas dan terukur.

Herman (1998: 133) strategi ekspositori dapat meliputi ceramah, stategi drill, metode tanya jawab, metode penemuan dan metode peragaan. Menurut Sumantri (2001: 45) ada perbedaan antara strategi ekspositori dan strategi ceramah. Dominasi guru dalam strategi ekspositori banyak di kurangi, guru tidak terus berbicara, informasi diberikan pada saat atau bagian yang di perlukan, seperti diawal pembelajaran, menjelaskan konsep-konsep dan prinsip baru, pada saat memberikan contoh kasus di lapangan dan sebagainnnya. Strategi ekspositori adalah suatu cara menyampaikan gagasan atau ide dalam memberikan informasi dengan lisan atau tulisan. Selanjutnya Dimyanti (1999: 172) mengatakan strategi ekspositori adalah memindahkan pengetahuan, ketrampilan, dan nilai-nilai kepada siswa. Peran guru yang penting adalah.

1) Menyusun program pembelajaran.

2) Memberi informasi yang benar.

3) Pemberi fasilitas yang baik.

4) Pembimbing siswa dalam perolehan informasi yang benar, dan

5) Penilai perolehan informasi. adalah.

Sedangkan peranan siswa

1) Pencari informasi yang benar.

2) Pemakai media dan sumber yang benar.

3) Menyelesaikan tugas dengan penilaian guru.

Adapun karakteristik pembelajaran ekspositori (Sanjaya, 2006: 179) diantaranya.

1) Strartegi ekspositori dilakukan dengan cara menyampaikan alat utama dalam melakukan strategi verbal, artinya bertutur 
secara lisan merupakan alat utama dalam melakukan stategi ini, oleh karena itu sering orang mengidentifikasikannya dengan ceramah.

2) Biasanya materi pelajaran yang disampaikan adalah materi yang sudah jadi, seperti data atau fakta, konsep-konsep tertentu yang harus dihafal sehingga tidak menuntut siswa untuk berfikir ulang.

3) Tujuan utama pembelajaran ini adalah penguasaan materi pelajaran itu sendiri, artinya setelah proses pembelajaran berakhir siswa diharapkan dapat memahami dengan benar, dengan cara mengungkapkan kembali materi yang telah diuraikan.

\section{Motivasi}

Dalam jurnal psikologi pendidikan dan pengembangan yang ditulis oleh Haryani (2014:33) dimana Murray mendefinisikan $n$-Ach sebagai kebutuhan untuk menyelesaikan sesuatu yang sulit, menguasai sesuatu dengan cepat dan mandiri, sedangkan McClelland mengatakan bahwa motivasi berprestasi dipengaruhi oleh dua faktor yaitu faktor instrinsik dan faktor ekstrinsik. Sedangkan Atkinson and Feather dalam (Singh: 2011) menyebutkan "suggested that achievement motivation is a combination of two personality variables: tendency to approach success and tendency to avoid failure" motivasi prestasi adalah kombinasi dari dua variabel kepribadian: kecenderungan untuk keberhasilan dan kecenderungan untuk menghindari kegagalan.

Pada kegiatan belajar, motivasi dapat dikatakan sebagai keseluruhan daya penggerak di dalam diri siswa yang menimbulkan kegiatan belajar, yang menjamin kelangsungan dari kegiatan belajar dan yang memberikan arah pada kegiatan belajar, sehingga tujuan yang dikehendaki oleh subyek belajar itu dapat tercapai.

Senada dengan apa yang di tulis long (2013: 138) "At the same time, the junior middle school students' learning motivation are influenced by the intrinsic motivation and extrinsic motivation, but extrinsic motivation affect mainly. The dominated intrinsic motivation including curiosity, thirst for knowledge, interest and competition etc; the dominated extrinsic motivation including current incentives, strengthening attract, desperate for peer re zcognition and admiration" dimana motivasi siswa SMP sangat dipengaruhi oleh faktor intrinsik dan ekstrinsik, dimana faktor intrinsik, berupa hasrat dan keinginan berhasil dan dorongan kebutuhan belajar, harapan akan cita-cita. Sedangkan faktor ekstrinsik adalah adanya penghargaan, lingkungan belajar yang kondusif, dan kegiatan belajar yang menarik. 
Motivasi beprestasi merupakan unsur yang sangat penting dalam proses pendidikan maupun dalam proses melaksanakan tugas dalam kehidupan sehari-hari. Motivasi acapkali dikaitkan dengan prestasi, yaitu sebagai faktor yang menjadi penyebab keberhasilan atau kegagalan dalam melaksanakan tugas, seperti yang di ungkapkan oleh Nugraha dalam ringkasan skripsinya dimana David C. McClelland menyebutkan adanya need for Achievement disingkat $N$-Ach dan motif berprestasi pada diri individu.

Dari definisi diatas, penulis menyimpulkan bahwa motivasi belajar merupakan dorongan atau rangsangan yang menggugah perasaan, pikiran sehingga mampu merubah tingah laku sesuai dengan apa yang diharapkan oleh motivator (guru) dengan dorongan yang telah diberikan oleh motivator maka akan dapat meningkatkan belajar yang tinggi dan akan belajar dengan sebaik-baiknya, sehingga mendapatkan ilmu pengetahuan yang diharapkan.

\section{METODE PENELITIAN}

Metode penelitian yang di gunakan dalam penelitian ini adalah penelitian kuantitatif. Penelitian ini menggunakan penelitian eksperimen dengan desain eksperimen nonequivalent control grub design dimana kelas eksperimen dan kelas kontrol tidak dipilih secara random (Sugiyono, 2012:79). Populasi pada penelitian ini adalah siswa kelas VIII semester genap SMPN 6
Semarang tahun ajaran 2017/2018. Siswa kelas VIII terdiri dari 8 kelas yang masing-masing kelas terdiri dari 32 siswa.

Rancangan tentang desain nonequivalent control grub design adalah.

$$
\frac{O_{1 x} O_{2}}{O_{3} O_{4}}
$$

Keterangan :

$\mathrm{O}_{1} \quad$ : hasil pretest kelompok eksperimen sebelum diperikan perlakuan.

$\mathrm{O}_{2}$ : hasil posttest kelompok eksperimen setelah diberikan perlakuan.

$\mathrm{X}$ : treatment yang diberikan pada kelompok exsperimen

$\mathrm{O}_{3} \quad$ : hasil pretest kelompok kontrol sebelum diberikan perlakuan.

$\mathrm{O}_{4} \quad$ : hasil postest kelompok kontrol.

\section{Variabel penelitian}

Dengan variabel:

1) Variabel bebas (X) Gaya mengajar guru disaat pembelajaran berlangsung.

2) Variabel terikat (Y) Motivasibelajar IPS siswakelas VIII SMPN 6 Semarang. 


\section{Alat dan teknik pengumpulan data}

Teknik pengumpulan data yang dilakukan pada penelitian ini yakni dengan menggunaan kuisioner atau angket untuk pengumpulan data. Metode angket dalam penelitian ini sebagai metode pengumpulan data utama untuk mendapatan data penerapan gaya mengajar guru dan motivasi belajar siswa.

Bentuk angket yang digunakan untuk mengukur gaya mengajar guru serta motivasi belajar siswa dengan menggunakan skala likert yang berbentuk ceklis. Skala likert mengharuskan responden untuk menjawab suatu pertanyaan dengan jawaban sangat setuju (SS), setuju (S), ragu-ragu(R), tidak setuju $(\mathrm{T})$, dan sangat tidak setuju (ST).dan masingmasing alternatif jawaban tersebut memiliki skor antara satu sampai lima, setiap item instrumen pada pertayataan mempunyai gradasi positif dan negatif.

\section{Validitas instrumen}

Validitas instrumen dapat menunjukan bahwa hasil dari suatu pengukuran menggambarkan segi atau aspek yang diukur (Sukmadinata, 2010:228). Suatu instrumen yang sudah dinyatakan valid berati alat ukur yang digunakan untuk mendapatkan data penelitian adalah valid.

Untuk mengetahui validitas instrumen maka digunakan rumus korelasi product moment dengan angka kasar. Rumus product moment dengan angka kasar yang digunakan adalah sebagai berikut (Arikunto, 2006:170):

$$
\begin{aligned}
& r x y= \\
& \frac{n \Sigma X Y-(\Sigma X)(\Sigma Y)}{\sqrt{\left[\left(n \Sigma X^{2}\right)-(\Sigma X)^{2}\right]\left[\left(n \Sigma Y^{2}\right)-(\Sigma Y)^{2}\right]}}
\end{aligned}
$$

Keterangan :

$$
\begin{array}{ll}
r x y & : \text { validitas instrument } \\
n & : \text { Jumlah respode } \\
\Sigma \mathrm{XY} & : \text { Jumlah nilai perbutir } \\
& \text { dikalikan nilai per } \\
& \text { responden } \\
\Sigma X & : \text { Jumlah nilai perbutir } \\
\Sigma Y & \text { : Jumlah nilai } \\
& \text { perresponden }
\end{array}
$$

Suatu instrumen dinyatakan valid apabila mempunyai $r$ hitung $>r$ kritis atau $r$ hitung. Sehingga instrumen yang digunakan valid apabila $r$ hitung > 0.30

\section{Reliabilitaas instrumen}

Reliabilitas berhubungan dengan keajegan atau ketetapan hasil pengukuran. Maksudnya suatu instrumen yang reliabel akan menunjukan hasil pengukuran yang sama walaupun digunakan dalam waktu yang berbeda. Pada penelitian ini akan dilakukan uji reliabilitas pada motivasi belajar IPS menggunakan rumus reliabilitas $\mathrm{KR}_{21}$. Suatu instrumen dinyatakan reliabel apabila $r_{\text {hitung }}>r_{\text {minimal }}$, yaitu $r_{\text {hitung }}>0,7$. Rumus relibilitas $\mathrm{KR}_{21}$ adalah sebagai berikut.

$$
\mathrm{r}=\left[\frac{\mathrm{k}}{\mathrm{k}-1}\right]\left[1-\frac{\mathrm{M}(\mathrm{k}-\mathrm{m})}{\mathrm{kS} 2}\right]
$$

Keterangan : 
K : Jumlah item dalam

instrumen

M : Rerata skor total

$S^{2} \quad$ : varian total

\section{Hipotesis statistik}

Hipotesis statistik terdiri dari dua macam, yaitu hipotesis nol $\left(\mathrm{H}_{\mathrm{o}}\right)$ dan hipotesis alternatif $\left(\mathrm{H}_{\mathrm{a}}\right)$. Biasanya hipotesis penelitian yang dirumuskan oleh peneliti akan menjadi hipotesis alternatif. Akan tetapi, hipotesis alternatif ini tidak dapat diuji secara langsung sehingga memerlukan hipotesis pembantu, yaitu hipotesis nol. Hipotesis nol inilah yang dapat diuji secara statistik dan sebagai penerimaan atau penolakan hipotesis nol yang dengan sendirinya berpengaruh pada terjadinya penolakan atau penerimaan hipotesis alternatif. Oleh karena itu, komposisi hipotesis statistik selalu menuliskan hipotesis nolnya terlebih dahulu baru kemudian menuliskan hipotesis alternatifnya. Hipotesis nol dan hipotesis alternatif penelitian ini adalah.

$\mathrm{H}_{0} \quad$ : Tidak terdapat perbedaan motivasi belajar siswa pada mata pelajaran IPS kelas VIII di SMPN 6 Semarang yang diajarkan menggunakan gaya mengajar ekspositori.

$\mathrm{H}_{\mathrm{a}}$ :Terdapat perbedaan motivasi belajar siswa pada mata pelajaran IPS kelas VIII di SMPN 6 Semarang yang

diajarkan menggunakan

gaya

mengajar ekspositori.

\section{Teknik analisis data}

Analisis data merupakan kegiatan mengelompokan data berdasarkan variabel dan jenis responden, mentabulasi data berdasarkan variabel dari seluruh responden, menyajikan data tiap variabel yang diteliti, melakukan perhitungan untuk menjawab rumusan masalah, dan melakukan perhitungan untuk menguji hipotesis yang telah diajukan (Sugiyono, 2012:147).

Langkah-langkah uji $\mathrm{t}$ adalah sebagai berikut:

Menghitungvariangabungan

$$
S=\frac{(n 1-1) S_{1}^{2}+(n 2-1) S_{2}^{2}}{n 1+n 2-2}
$$

Keterangan :

$\mathrm{S} \quad$ : varian gabungan

$\mathrm{n}_{1}$ : jumlah subjek kelompok eksperimen

$\mathrm{n}_{2} \quad$ : jumlah subjek kelompok kontrol

$\mathrm{S}_{1} \quad$ :variansi kelompok eksperimen

$\mathrm{S}_{2} \quad$ : variansi kelompok control

b) Menghitungharga t denganrumus :

Keterangan :

$$
t=\frac{x i-\bar{x}}{s \sqrt{\frac{1}{n 1}+\frac{1}{n 2}}}
$$

xi : rata - rata kelompok eksperimen

$\bar{x} \quad$ : rata - rata kelompok kontrol

$S \quad$ : varian gabungan 
$\mathrm{n}_{1} \quad$ : jumlah subjek kelompok eksperimen

$\mathrm{n}_{2} \quad$ : jumlah subjek kelompok kontrol

c) Mencari harga $t$ dari daftar, dengan $\alpha=$ 0,05 dan $\mathrm{dk}=\mathrm{n} 1+\mathrm{n} 2-2$

$\mathrm{n}_{1}=$ jumlah subjek kelompok eksperimen

$\mathrm{n}_{2}=$ jumlah subjek kelompok kontrol (Sudjana,1996:239)

kriteria hipotesis diterima adalah jika hasil $t_{\text {hitung }}>t_{\text {tabel }}$ pada taraf signifikansi $5 \%$. Tetapi apabila $t_{\text {hitung }}<t_{\text {tabel }}$ pada taraf signifikan $5 \%$ maka hipotesis ditolak.

\section{PEMBAHASAN}

Tabel 1. Gambaran umum skor pada kelas eksperimen

\begin{tabular}{ccc}
\hline $\begin{array}{c}\text { Sumber } \\
\text { Variasi }\end{array}$ & \multicolumn{2}{c}{ Kelas } \\
& $\begin{array}{c}\text { Eksperimen } \\
\text { Awal }\end{array}$ & Akhir \\
\hline Jumlah Siswa & 32 & 32 \\
Skor rata-rata & 162,56 & 165,19 \\
Skor tertinggi & 206 & 207 \\
Skor terendah & 121 & 130 \\
\hline
\end{tabular}

Tabel 2. Gambaran umum skor pada kelas kontrol

\begin{tabular}{ccc}
\hline $\begin{array}{c}\text { Sumber } \\
\text { Variasi }\end{array}$ & \multicolumn{2}{c}{ Kelas Kontrol } \\
Awal & Akhir \\
\hline Jumlah Siswa & 32 & 32 \\
Skor rata-rata & 156,69 & 152,13 \\
Skor tertinggi & 200 & 193 \\
Skor terendah & 126 & 108 \\
\hline
\end{tabular}

1. Hasil penelitian kelas eksperimen dengan menggunakan gaya mengajar ekspositori.

Hasil penelitian ini menunjukan bahwa gaya mengajar ekspositori yang terdapat perbedaan motivasi belajar siswa antara kelas eksperimen awal sebelum diberikan perlakuan dan kelas eksperimen akhir sesudah diberikan perlakuan. Hal ini terlihat dari hasil analisis uji perpedaan dua rata-rata pada kelas eksperimen diperoleh harga

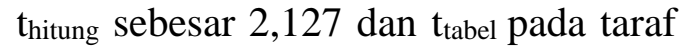
signifikan 5\% sebesar 1,695 dengan $\mathrm{dk}$ sebesar 31. Hal ini menunjukan bahwa $t_{\text {hitung }}$ lebih besar dari $t_{\text {tabel }}$ yang berati ada perbedaan motivasi belajar siswa yang diajarkan menggunaan gaya mengajar ekspositori.

Hasil penelitian ini didukung oleh teori yang dikemukakan oleh Suryosubroto (2009: 28) yaitu "pembelajaran merupakan serangkaian peristiwa yang direncanakan untuk disampaikan, untuk menggiatkan dan mendorong belajar siswa yang merupaan proses merangkai situasi belajar agar belajar lebih mudah dipahami". Pendapat tersebut sesuai dengan hasil penelitian, mengenai gaya mengajar ekspositori, hal ini ditunjukan pada hasil penelitian yang menunjukan nilai $t_{\text {hitung }}$ sebesar 2,127 lebih besar dari $t_{\text {tabel }}$ sebesar 1,695. Yang mengartikan bahwa ada perbedaan motivasi belajar siswa yang diajarkan menggunakan gaya mengajar ekspositori.

Hasil penelitian mengenai motivasi belajar siswa dalam penelitian 
ini didukung oleh teori yang dikemukankan oleh David McClelland dalam bukunya Uno (2006: 9) "A motive is the redintegration by a cue of a change in an affective situation, yang artinya motif merupakan implikasi dari hasil pertimbangan yang telah dipelajari (redintegration) dengan ditandai suatu perubahan pada situasi afektif", sumber utama motif dari rangsangan (stimulasi) perbedaan situasi sekarang dengan situasi yang diharapkan, sehingga tanda perubahan tersebut tampak pada adanya perbedaan afektif saat munculnya motif dan saat usaha pencapaian yang diharapkan. Motivasi dalam pengertian tersebut memiliki dua aspek, yaitu adanya dorongan dari dalam dan dari luar untuk mengadakan perubahan dari suatu keadaan pada keadaan yang diharapkan, dan usaha untuk mencapai tujuan. Hal ini ditunjukan dengan skor rata-rata dari kelas eksperimen yang awalnya 162,56 setelah dilakukanya treatmen skor rata-ratanya di kelas eksperimen akhir menjadi sebesar 165,19. Kebutuhan inilah yang akan menimbulkan dorongan atau motif tertentu, dimana diyakini bahwa jika perubahan itu dilakukan, maka tercapailah keadaan keseimbangan dan timbul rasa puas dalam diri individu.

\section{Hasil penelitian kelas kontrol dengan menggunakan gaya mengajar ceramah.}

Pada kelas kontrol yang menggunakan gaya mengajarceramah hasil penelitian menunjukan bahwa tida ada perbedaan motivasi belajar siswa antara kelas kontrol awal dan kelas kontrol akhir. Hal ini bisa dilihat dari hasil analisis perdedaan dua ratarata pada kelas kontrol dimana diperoleh nilai thitung sebesar-2,809 dan $t_{\text {tabel }}$ pada taraf signifikat $5 \%$ sebesar 1,695 dengan dk sebesar 31. Hal ini menunjukan bahwa thitung lebih kecil dari $t_{\text {tabel }}$ yang berati tidak ada perbedaan motivasi belajar siswa yang diajarkan menggunaan gaya mengajar ceramah.

Penelitian ini sejalan dengan hasil penelitian yang dilakukan oleh Gunawan (2007) dalam skripsinya yang berjudul pengaruh metode mengajar (ceramah, ceramahpraktikum, dan ceramah-pemberian tugas) terhadap hasil belajar biologi siswa di SMPN 1 Cikarang Barat, Bekasi. Yaitu siswa yang diajarkan dengan menggunakan metode ceramah saja memiliki hasil belajar rendah.

Ada beberapa faktor menurut (Gunawan, 2007: 52-53) dalam skripsinya yang bisa di jadikan pertimbangan mengapa hasil penelitian belajar siswa yang diajaran dengan menggunakan ceramah memiliki hasil yang rendah, yaitu:

1) Proses pembelajaran dengan metode ceramah membuat siswa tidak banyak berperan langsung dalam proses pembelajaran, artinya siswa lebih cenderung pasif.

2) Dengan metode ceramah membuat siswa cenderung lebih pasif karena dalam 
proses pembelajaran ini lebih berpusat pada guru (teacher centered instruction).

3) Dengan metode ceramah membuat siswa bosan, karena hanya mendengarkan guru untuk berceramah.

4) Metode pembelajaran seperti ini menjadikan siswa kurang menarik, karena siswa tidak dapat mencari, melihat dan mempraktikan materi yang dipelajari secara langsung 3 . karena metode ini terkesan seperti hafalan.

Hasil penelitian ini juga didukung oleh teori yang dikemukankan oleh Sanjaya (2006: 147) mendefinisikan "metode ceramah dapat diartikan sebagai cara menyajikan pelajaran melalui penuturan lisan atau penjelasan langsung kepada sekelompok siswa". Di kuatkan oleh Abu Ahmadi dan Joko Tri Prasetyo dalam skripsinya Sutarsih (2013 :6) mengungkapkan bahwa "metode ceramah ialah suatu metode didalam pendidikan dan pengajaran dimana cara menyampaikan pengertian-pengertian materi pengajaran kepada cara menyampaikan pengertian-pengertian materi pelajaran kepada anak-anak didik dilaksanakan dengan lisan oleh guru didalam kelas".

Dari beberapa pendapat diatas maka dapat disimpulkan bahwa metode ceramah adalah penyajian bahan pelajaran yang penyampaiannya mengunakan lisan. Hal ini yang mengakibatkan banyaknya siswa tidak banyak berperan langsung dalam proses pembelajaran, artinya siswa lebih cenderung pasif dikarenakan proses pembelajaran ini lebih berpusat pada guru (teacher centered instruction), siswa merasa bosan karena hanya mendengarkan guru untuk berceramah, serta siswa kurang tertarik dengan pembelajaran ceramah karena metode ini terkesan seperti hafalan.

\section{- Perbedaan kelas eksperimen (gaya mengajar ekspositori) dan kelas kontrol (gaya mengajar ceramah)}

Hasil perbedaan motivasi belajar siswa yang diajarkan menggunaan gaya mengajar ekspositori dengan yang diajarkan menggunakan gaya mengajar ceramah dapat di lihat pada tabel 4.13 dimana hasil penelitian menunjukan ada perbedaan motivasi belajar siswa antara penggunaan gaya mengajar ekspositori dan penggunaan gaya mengajar ceramah, hal ini dilihat dari hasil perhitungan uji $\mathrm{t}$ dua sampel dengan tabel Independent Samples Test di dapat nilai thitung sebesar 2,897 sedangkan $t_{\text {tabel }}$ sebesar 1,669 dengan dk sebesar 62. Karena nilai thitung lebih besar dari tabel maka terdapat perbedaan motivasi belajar siswa antara kelas eksperimen yang menggunakan gaya mengajar ekspositori dan kelas kontrol yang menggunakan gaya mengajar ceramah. Hasil menunjukan bahwa gaya mengajar ekspositori lebih efektif diterapkan pada mata pelajaran IPS 
dengan materi kedatangan bangsa barat ke Indonesia.

Hasil penelitian ini didukung dengan pendapat Sanjaya (2006: 179), strategi pembelajaran ekspositori adalah strategi pembelajaran yang menekanan kepada proses penyampaian materi secara verbal dari seorang guru kepada sekelompok siswa dengan maksud agar siswa dapat menguasai materi pelajaran secara optimal.

Materi pelajaran seakan-akan sudah jadi. Karena strategi ekspositori lebih menekankan kepada proses bertutur, makasering jugadinamakan strategi "chalk and talk". Strategi ekspositori digunakan dengan mengkombinasikan strategi ceramah, tanyajawab, diskusi kecil dan pemberian tugas. Pemberian tugas diberikan guru berupa soal-soal yang dikerjakan secara individual atau kelompok.

Hasil penelitian ini juga didukung dengan pendapat Dimyanti dan Mudjiono (2006: 172-173), mengatakan strategi ekspositori adalah memindahkan pengetahuan, ketrampilan, dan nilai-nilai kepada siswa. Peran guru yang penting adalah menyusun program pembelajaran, memberi informasi yang benar, pemberi fasilitas yang baik, pembimbing siswa dalam perolehan informasi yang benar, dan penilaian informasi. Penggunaan gaya mengajar ekspositori membuat motivasi belajar siswa lebih baik dibandingkan dengan gaya mengajar ceramah konvensional yang selama ini digunakan oleh guru IPS SMPN 6 Semarang. Dikarenakan gaya mengajar ekspositori dimana proses penyampaian materi pelajaran secara verbal dari seorang guru kepada peserta didik dengan maksud agar siswadapat menguasai materi pelajaran secara optimal, guru dapat memeriksa pekerjaan siswa secara individu, menjelaskan lagi kepada siswa secara individu, ini berati pembelajaran tidak berpusat pada guru, siswalebihdapataktif di pembelajaran ekspositor, kondisi seperti ini dapat memberikan banyak kesempatan pada siswa untuk mengembangkan diri dalam menemukan pengetahuan.

Penyampaian materi pelajaran merupakan ciri utama dalam strategi pembelajaran ekspositori, namun tidak berarti proses penyampaian materi tanpa tujuan pembelajaran. Justru tujuan itulah yang harus menjadi pertimbangan utama dalam penggunaan strategi ini. Karena itu sebelum strategi ini diterapkan terlebih dahulu guru harus merumuskan tujuan pembelajaran secara jelas dan terukur. Seperti kriteria pada umumnya, tujuan pembelajaran harus dirumuskan dalam bentuk tingkah laku yang dapat diukur atau berorientasi pada kompetensi yang harus dicapai oleh siswa.

Dengan strategi pembelajaran ekspositori guru mampu mengontrol urutan dan keluasan materi pembelajaran, ia dapat mengetahui sampai sejauh manasiswa menguasai bahan pelajaran yang disampaikan. Melalui strategi pembelajaran 
ekspositori selain siswa dapat mendengar melalui penuturan (kuliah) tentang suatu materi pelajaran, juga sekaligus siswa bisa melihat atau mengobservasi (melalui pelaksanaan demonstrasi).

Dalam hal ini minat belajar dan persepsi siswa tentang gaya mengajar guru secara bersama-sama mempengaruhi motivasi belajar siswa. Oleh karena itu, guru hendaknya memvariasikan gaya mengajar yang sesuai dengan materi yang akan di ajarkan kepada siswa agar siswa selalu antusias dalam mengikuti kegiatan pembelajaran.

\section{SIMPULAN}

Berdasarkan hasil penelitian dan pembahasan pada bab empat dapat disimpulkan bahwa :

1) Hasil penelitian menunjukan motivasi siswa dari kelas eksperimen, yaitu ada perbedaan motivasi belajar siswa yang diajarkan menggunakan gaya mengajar ekspositori, ini terlihat dari hasil penelitian yang menunjukan nilai $t_{\text {hitung }}$ sebesar 2,127 lebih besar dari $t_{\text {tabel }}$ sebesar 1,695, serta skor rata-rata uji akhir (Posttest) lebih tinggi dibandingkan dengan uji awal (pretest), yaitu 165,19>162,56. Maka dapat disimpulkan bahwa gaya mengajar ekspositori memberikan dampak positif terhadap motivasi belajar siswa pada kelas eksperimen.
2) Dari hasil penelitian menunjukan motivasi pada kelas kontrol, yaitu tidak ada perbedaan yang signifikat motivasi belajar siswa yang diajarkan menggunakan gaya mengajar ceramah, hal ini terlihat dari hasil penelitian yang menunjukan thitung sebesar $-2,809$ dan $t_{\text {tabel }}$ sebesar 1,695, serta skor rata-rata uji akhir (Posttest) lebih rendah dibandingkan dengan uji awal (pretest), yaitu 152,13< 156,69 .

3) Dari hasil perhitungan uji hipotesis dengan menggunakan uji $\mathrm{t}$ dua sampel (Independent Samples Test) didapat harga nilai $t_{\text {hitung }}$ sebesar 2,897 dari tabel distribusi pada taraf signifikan $5 \%$ dengan derajat kebebasan $(\mathrm{dk}=32+32-2=$ 62), diperoleh harga $t_{\text {tabel }}$ sebesar 1,669. Maka thitung 2,897 lebih besar dari $t_{\text {tabel }} 1,669$ ( $t_{\text {hitung }} 2,897$ $>t_{\text {tabel }}$ 1,669) maka $H_{o}$ ditolak. Dengan demikian terdapat perbedaan motivasi belajar siswa mata pelajaran IPS pada kelas VIII SMPN 6 Semarang yang diajarkan menggunakan gaya mengajar ekspositori.

\section{SARAN}

Berdasarkan hasil penelitian, maka terdapat beberapa saran sebagai berikut:

1) Guru diharapkan menerapkan gaya mengajar yang menarik dan bervariasi.

2) Untuk para peneliti yang akan melakukan penelitian pada 
bidang kajian yang sama hendaknya memperhatikan keterbatasan-keterbatasan yang ada dalam penelitian ini agar hasil yang diperoleh lebih sempurna, seperti melaksanakan penelitian dalam subjek penelitian yang lebih luas dan menggunakan strategi atau gaya mengajar selain ekspositori yang berpengaruh terhadap peningkatan motivasi belajar siswa.

\section{DAFTAR PUSTAKA}

Arikunto, Suharsimi. 2006. Prosedur Penelitian Suatu Pendekatan Praktik. Jakarta : PT. Rineka Cipta.

Dimyanti, \& Mudjiono. 1999. Belajar dan Pembelajaran. Jakarta : Rineka Cipta.

Dimyanti, \& Mudjiono. 2006. Belajar dan Pembelajaran. Jakarta : Rineka Cipta.

Gunawan, edi. 2007. Pengaruh Metode Mengajar (Ceramah, CeramahPraktikum dan CeramahPemberian tugas) Terhadap Hasil Belajar Biologi Siswa (Sebuah Eksperimen di SMPN 1 Cikarang Barat-Bekasi). Skripsi. Universitas Islam Negeri Syarif Hidayatuallah. Jakarta.

Herman, Hudoyo. 1998. Ilmu Pendidikan. Surabaya : Usaha Nasional.
Long, Chunmei, dkk. 2013. 'The Study of Student Motivation on English Learning in Junior Middle School -A Case Study of No.5 Middle School in Gejiu'. Dalam jurnal Canadian Center of Science and Education. Vol. 6. No. 9. Hal 136-145.

Mulyasa. 2008. Menjadi Guru Profesional menciptakan Pembelajaran Kreatif dan Menyenangkan. Bandung: PT. Remaja Rosdakarya.

Nani M. S \& Syamsul Yusuf. 2013. Perkembangan Peserta Didik. Jakarta : Rajawali Pers.

Rukyawati. 2013. 'Meningkatkan kreativitas siswa dengan penggunaan metode ekspositori pada mata pelajaran sejarah kelas XII SMAN 10 Pekanbaru'. Dalam jurnallentera. Vol VI. No 15. Hal 95-108.

Sanjaya, Wina. 2006. Strategi Pembelajaran Berorientasi Standar Proses Pendidikan. Jakarta : Putra Grafika.

Singh, Kulwinder. 2011. 'Study Of Achievement Motivation In Relation To Academic Achievement Of Students'. Dalam International Journal of Educational Planning \& Administration.Volume 1. Number 2.

Sudjana. 1996. Disain dan Analisis Eksperimen. Bandung : Tarsito. 
Sugiyono. 2012. Metode Penelitian

Kuantitatif dan $R \& D$. Bandung : Alfabeta.

Sukmadinata, Nana Syaodih. 2010. Metode Penelitian Pendidikan. Bandung : Remaja Rosdakarya.

Sumantri, Numan. 2001. Menggagas Pembaharuan Pendidikan. Bandung : Remaja Rosdakarya.
Sutarsih, Sri. 2013. Pengaruh Penerapan metode Ceramah Bervariasi terhadap Peningkatan Hasil Belajar Siswa Pada Mata Pelajaran IPS di SMK Al-Hidayah Lestari. Skripsi. Universitas Islam Negeri Syarif Hidayatuallah. Jakarta.

Uno, Hamzah B. 2006. Teori Motivasi dan Pengukurannya. Jakarta : PT Bumi Aksara. 